Revta brasil. Bot., São Paulo, V.23, n.4, p.349-357, dez. 2000

Review Article

\title{
Intracellular and intercellular compartmentation of carbohydrate metabolism in leaves of temperate gramineae
}

\author{
CHRISTOPHER J. POLLOCK ${ }^{1,3}$, JOHN FARRAR ${ }^{2}$, OLGA A. KOROLEVA ${ }^{2}$, \\ JOE A. GALLAGHER ${ }^{1}$ and A. DERI TOMOS ${ }^{2}$
}

\begin{abstract}
This review considers the importance of compartmentation in the regulation of carbohydrate metabolism in leaves. We draw particular attention to the role of the vacuole as a site for storage of soluble sugars based on sucrose, and discuss briefly their characteristic metabolism. We also point out inconsistencies between the observed properties of vacuoles and the behaviour in vitro of the enzymes of fructan biosynthesis that do not support the hypothesis that the vacuole is the site of synthesis as well as of storage. We also consider compartmentation of carbohydrate metabolism between different cell types, using mainly our studies on leaves of temperate C3 gramineae. Here we present evidence of significant differences in carbon metabolism between epidermis, mesophyll, bundle sheath and vasculature based upon both single-cell sampling and immunolocalisation. The implications of these differences for the control of metabolism in leaves are discussed.

RESUMO - (Compartimentação intracelular e intercelular do metabolismo de carboidratos em folhas de gramíneas de regiões temperadas). Esta revisão considera a importância da compartimentação para a regulação do metabolismo de carboidratos nas folhas, com destaque especial para o papel do vacúolo como local de armazenamento de carboidratos solúveis derivados da sacarose e seu característico metabolismo. Inconsistências entre as propriedades dos vacúolos e o comportamento in vitro das enzimas de biossíntese de frutanos são também destacadas, uma vez que não dão suporte à hipótese de que o vacúolo, é o local de síntese e armazenamento desses compostos. A compartimentação do metabolismo de carboidratos em diferentes tipos de células também é considerada em folhas de gramíneas C3 de regiões temperadas. Através de estudos com células isoladas e de imunolocalização são apresentadas evidências de diferenças significativas entre o metabolismo de carbono em epiderme, mesófilo, bainha de feixes e tecidos vasculares; são discutidas as implicações dessas diferenças no controle do metabolismo foliar.
\end{abstract}

Key words - Leaf, carbohydrate, compartmentation, mesophyll, vacuole

\section{Introduction}

The majority of the theories of metabolic control of carbon metabolism have been derived from measurements of the abundance of key metabolites, enzymes or gene sequences in tissue extracts. Preparation of tissue extracts destroys positional information at two scales; the location of processes within cells and the location of processes within tissues. Within mesophyll cells it is known that carbon is partitioned between chloroplast, cytosol and vacuole (Stitt 1996), but much less is known about the significance of partitioning between differ-

1. Institute of Grassland and Environmental Research, Plas Gogerddan, Aberystwyth SY23 3EB, Wales, UK

2. School of Biological Sciences, University of Wales Bangor, Bangor, Gwynedd LL57 2UW, Wales, UK

3. Corresponding author: chris.pollock@bbsrc.ac.uk ent tissues within the leaf. The potential importance of such partitioning is, however, large. In wheat leaves, less than $50 \%$ of the volume is occupied by photosynthetic mesophyll cells (Jellings \& Leech 1982), and thus any uneven distribution of metabolites or enzymes could significantly affect estimates of both flux and abundance for the primary processes of carbon fixation and metabolism.

In leaves of temperate C3 gramineae, the situation is made more complex by the different chemical patterns of carbon metabolism. Starch does accumulate in chloroplasts, but only to small amounts, with sucrose and sucrosyl fructans acting as the major temporary storage carbohydrates (Pollock et al. 1999). In this review, we consider the significance of compartmentation within photosynthetic cells and between these and non-photosynthetic cells in terms of the regulation of photosynthetic carbon metabolism. Where appropriate, we compare these processes with those occurring in $\mathrm{C} 3$ dicots. We propose that these studies have 
functional significance because of the variable occurrence of end-product inhibition of photosynthesis in leaves, and the possibility that this may be linked to either the chemistry or physiology of storage (Pollock \& Farrar 1996).

\section{Intracellular Partitioning}

The partitioning of current photosynthate within autotrophic cells involves movement of material between chloroplasts, cytosol, mitochondria and vacuoles (Pollock \& Kingston-Smith 1997). The best evidence for regulation of such interchanges comes from studies on chloroplasts. The autocatalytic nature of the photosynthetic carbon reduction pathway requires tight control of the rate of export of phosphorylated intermediates in order to maintain optimal rates of regeneration of RuBP. This is achieved via the tight coupling of the export of triose phosphates with the import of Pi through the phosphate translocator in the chloroplast envelope (Stitt 1996). Additionally, the rate of utilisation of triose phosphate in sucrose biosynthesis is linked to the abundance of substrate and to the rate of utilisation of product via the fructose 2,6 bisphosphate regulatory cycle and via control of sucrose phosphate synthase activity (Huber et al. 1995, Stitt 1996,). There is good evidence from a range of experimental systems (Stitt 1996) that the daily pattern of carbon fixation in leaves is associated with progressive shifts in partitioning between the retention of carbon within the chloroplast (leading to optimal RuBP regeneration), the export of carbon (leading to the biosynthesis of sucrose) and the further retention of carbon within the chloroplast (leading to starch accumulation).

There is a lot less information on the regulation of exchanges between other compartments. Mitochondria in the leaves of $\mathrm{C} 3$ plants import two major substrates for the TCA cycle - pyruvate and (unlike animals) malate; oxaloacetate can also be transported. The relative fluxes of these compounds are unknown, but the presence of alternatives to pyruvate is another example of the flexibility of plant metabolism (Douce \& Neuburger 1989). Measuring the concentrations of pyruvate and malate available to the mitochondria is complicated by inter- and intra-cellular compartmentation. All the evidence suggests that, in the dark, the rate of import of these substrates is determined by the rate of respiration, which is itself under control of adenylate turnover (Amthor 1989); more formally, the control of flux lies mainly with adenylates (Fell 1997).

In the light, at least part of the TCA cycle is active but the flux through it is usually lower than in darkness, although it is very hard to measure (Kromer 1995, Graham 1980). Thus the import of pyruvate and malate will be lower. At the same time, photorespiration is the cause of a different set of mitochondrial fluxes usually larger than those associated with dark respiration: in the leaves of $\mathrm{C} 3$ plants, mitochondria import glycine, which is decarboxylated to serine, which is then exported (Douce $\&$ Neuburger 1989).

In a number of sink tissues, it is known that accumulation of low molecular weight sugars in vacuoles is under tight metabolic control and there is good evidence for the occurrence of specific transporters at the tonoplast (Pollock \& Kingston-Smith 1997). It appears that transport here is against a concentration gradient, with the process powered via the ATP-dependent establishment of a $\mathrm{pH}$ gradient that is linked to sucrose uptake via a sucrose-proton antiporter (Bush 1993). This results in a significant compartmentation of sucrose and/or hexose, with higher concentrations in the vacuolar sap than in the cytosol.

The situation in leaves is much less clear. In many species, chloroplast starch is the major stored form of carbohydrate, and kinetic analysis suggests that much of the soluble sugar (mainly sucrose) is rapidly translocated out of the leaf. In others, such as temperate $\mathrm{C} 3$ grasses and cereals, sucrose is both stored and further metabolised in leaves, and starch is a relatively minor component (Cairns et al. 2000, Farrar et al. 2000). Studies on rapidly isolated vacuoles from cereal leaves showed that sucrose was quickly partitioned between cytosol and vacuole, with kinetics similar to the rate of synthesis (Kaiser et al. 1982). A kinetic analysis of sucrose uptake suggested that active accumulation did not occur (Kaiser \& Heber 1984), and it was suggested that vacuolar and cytosolic concentrations were similar (Pollock \& Kingston-Smith 1997). This model has, however, been challenged by Heldt and co-workers 
for both barley and spinach (Winter et al. 1993, 1994). They used the techniques of non-aqueous fractionation and stereological analysis to estimate the amount of sucrose in the total cytosolic, stromal and vacuolar pools together with the volume of these pools (Gerhardt \& Heldt 1984). A summary of some of these data is given in table 1, suggesting that there is active retention of sucrose in the cytosol of both sucrose- and starch-storing leaves. However, their cytosolic fraction will include phloem contents, which will artefactually increase its concentration. Unfortunately, the technique of single-cell sampling, which gives almost pure samples of vacuolar sap from a number of plant tissues (Tomos et al. 1992), produces a mixture of cytosol and vacuole when applied to leaf mesophyll cells (Koroleva et al. 1997). Currently, therefore, it is not possible to assess with certainty the significance of the vacuole in the active storage of sucrose and hexose in leaves. However, the large volume of the vacuole when compared with cytosol means that a significant proportion of the low molecular weight soluble sugars in the leaf will reside in this compartment, even if the cytosolic concentrations are higher.

The vacuole is, however, undoubtedly involved in the storage of higher molecular weight soluble sugars based on sucrose, particularly fructans and the raffinose-family oligosaccharides (RFO; Pollock et al. 1999). Analysis of enzymatically-prepared vacuoles from a range of species and tissues where these compounds accumulate has indicated both the presence of the compounds themselves and, in some cases, the enzymes thought to be involved in their synthesis (tables 2 and 3). In the case of RFO synthesis in leaves of Ajuga reptans, the enzymes that catalyse the formation of galactinol and stachyose (processes thought to occur in the cytosol) could not be found in purified vacuoles, whereas the reversible galactosyl transferase that catalysed chain elongation was present apparently exclusively in vacuoles. This is consistent with the first stages of synthesis being cytosolic, followed by transport of stachyose into the vacuole and subsequent chain elongation (Bachmann et al. 1994, Bachmann \& Keller 1995).

Unfortunately, the situation in leaves of temperate gramineae that accumulate fructans is less clearcut. The majority of the fructans in barley leaves, together with the measurable fructosyl transferase activities thought to be responsible for their synthesis, can be isolated from vacuoles (Wagner et al. 1983, Wagner \& Wiemken 1986, Matile 1987). There is, however, a considerable discrepancy between the conditions within the vacuole and the conditions needed for in vitro fructan synthesis (Cairns et al. 2000). To obtain in vitro high rates of fructan synthesis and products that are similar in chemical structure to native fructan, high concentrations of sucrose $(>300 \mathrm{mM})$ and high concentrations of enzyme protein ( $>5 \mathrm{~g}$ fresh mass equivalents $\mathrm{cm}^{-3}$ ) are needed (Cairns et al. 1989, Cairns 1995). These do not equate to measurements of concentrations in isolated vacuoles, which are considerably lower (Cairns et al. 2000). Although it is possible that some form of metabolic channelling exists (Dixon et al.

Table 1. Calculations of metabolite concentrations (mM) in the subcellular compartments of spinach and barley leaves.

\begin{tabular}{lllcc}
\hline Species & Metabolite & Stroma & Cytosol & Vacuole \\
\hline Spinach & F 1,6 BP & 0.55 & 0.14 & $\leq 0.001$ \\
& UDP glucose & 0.07 & 1.7 & $<0.007$ \\
& Sucrose & $<.8$ & 53 & 11 \\
& Glutamine & 20 & 24 & 0.58 \\
& Nitrate & $<4$ & $\leq 8$ & $\geq 25$ \\
Barley & Sucrose & $<5$ & 232 & 20 \\
(leaves illuminated for 9 $\mathrm{h}$ ) & Glutamine & 17.2 & 25.7 & $<0.12$ \\
& Nitrate & $<25$ & $<30$ & 186 \\
\hline
\end{tabular}

Concentrations were derived from stereological estimates of volume and determination of metabolites by non-aqueous fractionation. $\mathrm{F}$ 1,6 BP; fructose 1,6 bisphosphate.

From Winter et al. 1993; 1994. 
Table 2. Sub-cellular distribution of carbohydrates and enzymes involved in fructan metabolism in leaves of barley.

\begin{tabular}{lc}
\hline Metabolite/enzyme activity & $\begin{array}{c}\text { Percentage of total } \\
\text { activity found in } \\
\text { vacuoles }\end{array}$ \\
\hline Fructose & 107 \\
Glucose & 109 \\
Sucrose & 65 \\
Fructan (trisaccharides) & 87 \\
Fructan (tetrasaccharides and larger) & 86 \\
Sucrose:sucrose fructosyl transferase & 92 \\
Invertase & 81 \\
Fructan exohydrolase & 94 \\
\hline
\end{tabular}

Vacuolar distribution was estimated using $\alpha$-methyl mannosidase as a vacuolar marker and comparing activities in isolated mesophyll protoplasts and the purified vacuoles liberated from such protoplasts. All determinations were made using illuminated detached leaves that were actively accumulating fructan except that for fructan exohydrolase, where protoplasts were prepared from leaves of whole seedlings undergoing fructan turnover. From Wagner et al. 1983; Wagner \& Wiemken 1986.

1997), it is equally possible that synthesis occurs elsewhere and that newly-synthesised fructan and the enzymes responsible are moved into the vacuole for storage. Such a suggestion has been made by Kaeser (1983) on the basis of ultrastructural studies of Jerusalem artichoke tubers. Measurements of hydrolytic activity (table 2) indicate that these enzymes are also in the vacuole. Here affinities for the substrate are much higher and there is less need to consider alternative patterns of compartmentation. It would appear, therefore, that there is good evidence for a role for the vacuole in carbohydrate storage, but some doubt over the involvement of vacuolar processes in the biosynthesis of these polymers.

\section{Tissue Partitioning}

It seems obvious that there must be some elements of tissue partitioning of carbon within many leaves, including those of temperate gramineae, given the range of tissue types and the apparent concentration difference between sucrose in mesophyll cells (20-200 mM) and phloem (500$1000 \mathrm{mM}$, Winter et al., 1992). Direct demonstration of partitioning, however, is not straightforward because of the difficulties involved in mechanical dis- section and the almost universal presence in leaves of hydrolytic enzymes that can degrade sucrose, starch and fructans whenever tissues are damaged. Histochemical analysis of starch granule accumulation in barley chloroplasts showed differences in both appearance and diel kinetics between mesophyll cells and those of the photosynthetic parenchymatous bundle sheath (Williams et al. 1989). Immunohistochemical analysis of the distribution of acid invertase within barley leaves also indicated non-uniformity, with considerably greater antigen abundance in the vicinity of the vascular bundles than in the interveinal mesophyll (Kingston-Smith \& Pollock 1996).

It has, however, been the development of singlecell analysis methods (Tomos \& Leigh 1999) that has permitted an unequivocal estimate of the extent of tissue compartmentation of carbon metabolism in cereal leaves. The samples of tissue sap are collected into an oil-filled glass microcapillary mounted on a micromanipulator. The capillary is inserted through the cell wall whilst the tissue is observed under a stereomicroscope. The turgor pressure within the cell forces the cell sap into the capillary and this sample can then be expelled onto the surface of a

Table 3. Subcellular distribution of carbohydrates and enzymes involved in the synthesis of raffinose-series oligosaccharides leaves of Ajuga reptans.

\begin{tabular}{lc}
\hline Metabolite/enzyme activity & $\begin{array}{c}\text { Percentage of total } \\
\text { activity found in } \\
\text { vacuoles }\end{array}$ \\
\hline Glucose & 7 \\
Galactose & 134 \\
Sucrose & 10 \\
Galactinol & 13 \\
Raffinose & 60 \\
Stachyose & 106 \\
Higher oligosaccharides & 108 \\
Galactinol synthase & 3 \\
Stachyose synthase & 8 \\
Galactan:galactan galactosyl transferase & 106 \\
\hline
\end{tabular}

Vacuolar distribution was estimated using $\alpha$-methyl mannosidase as a vacuolar marker and comparing activities in isolated protoplasts and the purified vacuoles liberated from such protoplasts. From Bachmann \& Keller 1995. 
glass slide under a layer of water-saturated paraffin oil, sub-sampled by picolitre constriction pipette and the sub-samples analysed. Assay of sugars and malate is via enzyme-linked reduction of pyridine nucleotides that are then measured fluorimetrically (Koroleva et al. 1998, 2000). The experimental challenge was to be able to measure accurately fructans in the presence of sucrose. This was overcome by using sucrose phosphorylase specifically to cleave sucrose (Harrison et al. 1997) and yeast invertase in excess to degrade both sucrose and fructan (Koroleva et al. 1998). The resultant hexoses could be assayed directly.

Barley plants were treated to stimulate sucrose accumulation, and hence to induce fructan accumulation (Wagner et al. 1983, Housley \& Pollock. 1985, Simpson et al. 1991). In separate experiments, roots were cooled to reduce sink activity, and carbon fixation was increased by increasing the irradiance (Koroleva et al 1997). The results obtained for measurements on epidermal, mesophyll and parenchymatous bundle sheath cells are summarised in table 4 . Significant differences between the three cell types were observed. Epidermal cells contained low con- centrations of sucrose, glucose and fructose, and no fructan. Experimental treatments that promoted sucrose and fructan accumulation did not affect the sugar contents of these cells. The majority of the soluble carbon in epidermal cells was as malate (Frike et al, 1994, Koroleva et al. 2000). By contrast, mesophyll and parenchymatous bundle sheath cells accumulated sucrose after both environmental treatments, together with significant amounts of fructan. The ratio between sucrose and fructan differed markedly, however, between the two cell types. The fructan to sucrose ratio was much higher under both treatments for parenchymatous bundle sheath cells, which is consistent with a gradient of sucrose concentration between the mesophyll cells and the site of active vein loading in the phloem parenchyma (Koroleva et al., 1998, 2000). ${ }^{14} \mathrm{CO}_{2}$ feeding to the leaves, followed by analysis of the radioactivity in single-cell samples using accelerator mass spectrometry (Zondervan \& Sparks 1997) indicated that the sucrose pool in mesophyll cells rapidly reached isotopic equilibrium with the external ${ }^{14} \mathrm{CO}_{2}$. By contrast, bundle sheath cells had a lower specific activity, suggesting that there were significant unla-

Table 4. Carbohydrate concentrations $(\mathrm{mM} \pm \mathrm{sd})$ in sap samples from single cells of barley leaves.

\begin{tabular}{|c|c|c|c|c|}
\hline Cell type & Sugar & Control & After sink cooling & After high light \\
\hline \multirow[t]{4}{*}{ Epidermis } & Glucose & $4 \pm 5$ & $5 \pm 3$ & $\mathrm{~nm}$ \\
\hline & Fructose & $5 \pm 4$ & nd & $\mathrm{nm}$ \\
\hline & Sucrose & $8 \pm 3$ & $8 \pm 1$ & $\mathrm{~nm}$ \\
\hline & Fructan* & nd & nd & $\mathrm{nm}$ \\
\hline \multirow[t]{4}{*}{ Mesophyll } & Glucose & $7 \pm 4$ & $35 \pm 17$ & $34 \pm 4$ \\
\hline & Fructose & $6 \pm 8$ & $6 \pm 10$ & $\mathrm{~nm}$ \\
\hline & Sucrose & $90 \pm 20$ & $169 \pm 47$ & $128 \pm 13$ \\
\hline & Fructan* & nd & $194 \pm 36$ & $148 \pm 27$ \\
\hline \multirow[t]{4}{*}{ Bundle Sheath } & Glucose & nd & $7 \pm 6$ & $27 \pm 10$ \\
\hline & Fructose & nd & $1 \pm 2$ & $\mathrm{~nm}$ \\
\hline & Sucrose & $16 \pm 1$ & $96 \pm 17$ & $107 \pm 27$ \\
\hline & Fructan* & nd & $177 \pm 77$ & $420 \pm 152$ \\
\hline
\end{tabular}

nd: not detectable. nm: not measured. * fructan concentrations are as $\mathrm{mM}$ hexose equivalents. From Koroleva et al. 1998. 
belled pools of sucrose, and perhaps that these cells were involved in refixation of carbon dioxide released by respiration from within the vascular bundles (Koroleva et al., 2000). It has been suggested (Labhart et al. 1983) that fructan synthesis in leaves serves to stabilise the sucrose concentration at levels that would prevent adverse effects. If this is so, then the observations summarised above indicate that the process must also be considered in conjunction with the sequestration of sucrose both within the vasculature and within individual cell types.

There are two lines of evidence to suggest that this latter process may be significant. Firstly, we have calculated the mean sucrose content of cell sap from the cell types that can easily be sampled by single cell analysis (comprising about $70 \%$ of tissue volume). When we compared this with the sucrose content of whole leaf extracts from replicate leaves, we were only able to account for some $60 \%$ of the total leaf sucrose, suggesting that the remainder is accumulated within the vasculature (comprising only about $6 \%$ of tissue volume) (Koroleva et al. 1998). The second line of evidence relates to the distribution of invertase protein and activity. As mentioned above, invertase protein appears to be immunologically localised around the veins (Kingston-Smith \& Pollock 1996). We used measurements of the rate of sucrose hydrolysis in single-cell samples to estimate soluble invertase activity and then compared it to extractable activity in whole-leaf extracts. In this case, only ca $9 \%$ of the total soluble activity was present in cell sap from epidermal, mesophyll and parenchymatous bundle sheath cells (table 5; Koroleva et al., 1997).

Based on these observations, we propose that there is extensive compartmentation of primary carbon metabolism within leaves of temperate gramineae. Epidermal cells appear to be buffered from environmentally-induced changes in assimilate abundance, with mesophyll and parenchymatous bundle sheath cells showing differential responses of starch, sucrose and fructan metabolism. There is also strong circumstantial evidence that significant elements of carbon metabolism are also localised in the vasculature, although technical limitations make it difficult to measure these directly.
Table 5. Distribution of acid invertase activity in samples from different cell types within barley leaves.

\begin{tabular}{lc}
\hline Sample & $\begin{array}{c}\text { Acid invertase activity } \\
\left(128 \mathrm{mmol}^{-1} \text { sucrose }\right. \\
\left.\text { cleaved } \mathrm{h}^{-1} \cdot \mathrm{g}^{-1} \text { fresh wt. }\right)\end{array}$ \\
\hline Whole tissue & 30 \\
Epidermal cells & 2 \\
Mesophyll cells & 4 \\
Parenchymatous bundle sheath cells & 2 \\
\hline
\end{tabular}

From Koroleva et al. 1997.

We know that the induction of fructan metabolism in leaves is associated with changes in the pattern of gene expression (Cairns \& Pollock 1988). Recently we have developed techniques to extract, amplify and assess the relative abundance of specific mRNA species from single cell samples (Gallagher et al. 2001). In initial experiments, we have shown that transcript abundance for a barley fructosyl transferase (sucrose-fructan 6-fructosyltransferase; Sprenger et al. 1995) increases in both mesophyll and bundle sheath cells in response to increased sucrose contents (figure 1; Koroleva et al. 2001). Further development of this approach should enable us to pinpoint the location and timing of gene expression changes in response to alterations in assimilate abundance and to extend this to analysis of possible down-regulation of key photosynthetic processes.

\section{Conclusions}

Specialisation of function is a key element in the evolution of higher multicellular organisms. Morphological analysis of vascular plants provides ample examples of such specialisation at the organ, tissue, cellular and sub-cellular level. It is, perhaps, a consequence of the resolution of "traditional" biochemical techniques that studies on metabolic specialisation have tended to emphasise the physical location of specific pathways or enzymes rather than spatial differences in flux or metabolic control. Unfortunately, plant responses to edaphic or biotic changes are often exhibited, at least initially, precisely at the latter level. The development of techniques such as image analysis, reporter genes, in situ hybridisation and single cell analysis offers new 
A) Samples taken at $8 \mathrm{~h}$ into the photoperiod from control plants.

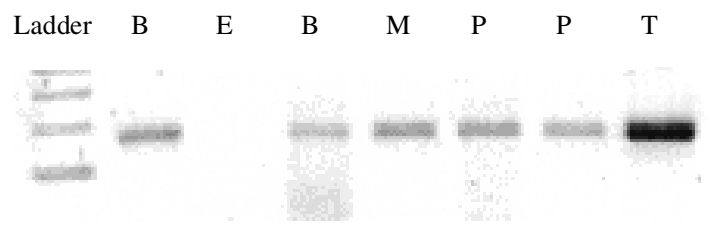

6- SFT fragment 262 bp

B) Samples taken at $8 \mathrm{~h}$ into the photoperiod from cooled plants or from cut leaves illuminated for $24 \mathrm{~h}$.

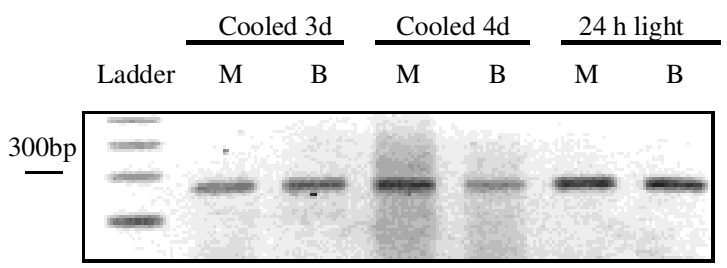

C) Samples taken from leaves after dark period; cut leaves illuminated for $24 \mathrm{~h}$; cut leaves in $200 \mathrm{mM}$ sucrose in the dark for $24 \mathrm{~h}$.

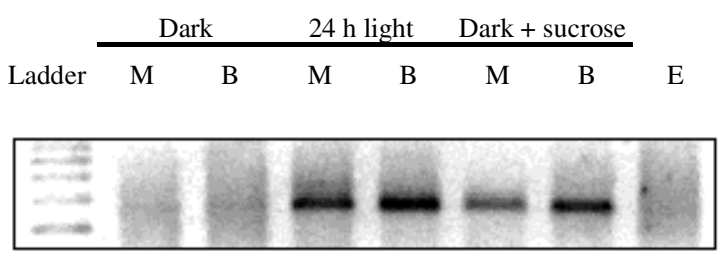

6-SFT fragment $262 \mathrm{bp}$

Figure 1. Relative abundance of mRNA for sucrose-fructan 6fructosyl transferase (6-SFT) in samples of barley leaves. (M), single-cell samples from mesophyll cells; (B), single-cell samples from bundle sheath cells; (E) single-cell samples from epidermal cells: (P), phloem parenchyma, sampled from cut surfaces; (T), total cell extract. Fructan accumulation was induced by cooling intact plants, by illuminating excised leaves or by feeding exogenous sucrose to excised leaves in the dark.

From Koroleva et al. 2001.

opportunities to analyse the dynamics of metabolism at the tissue level. The leaves of temperate $\mathrm{C}_{3}$ grasses and cereals function in an environment where marked changes in the supply of and demand for fixed carbon occur on an annual, daily and momentby moment basis. The flux through primary carbon metabolism is large and the effects of environmental changes on such metabolism are equally significant.
As such, they offer an excellent model system for the application of these approaches and our understanding of the central importance of compartmentation of metabolism is likely to grow rapidly over the next few years.

Acknowledgements - We acknowledge the Biotechnology and Biological Sciences Research Council (UK) for financial support for our work in the area of this review and the University of Wales Bangor for financial support for O.A.K. We are grateful to Jo Spikes for assistance in the preparation of the manuscript.

\section{References}

AMTHOR, J.S. 1989. Respiration and crop productivity. Springer, Berlin.

BACHMANN, M. \& KELLER, F. 1995. Metabolism of the raffinose family oligosaccharides in leaves of Ajuga reptans L. Inter- and intracellular compartmentation. Plant Physiology 109:991-998.

BACHMANN, M., MATILE, P. \& KELLER, F. 1994. Metabolism of the raffinose family oligosaccharides in leaves of Ajuga reptans L. Cold acclimation, translocation, and sink to source transition: discovery of chain elongation enzyme. Plant Physiology 105:1335-1345.

BUSH, D.R. 1993. Proton-coupled sugar and amino-acid transporters in plants. Annual Review Plant Physiology and Plant Molecular Biology 44:513-542.

CAIRNS, A.J. 1995. Effects of enzyme concentration of oligofructan synthesis from sucrose. Phytochemistry 40:705-708.

CAIRNS, A.J. \& POLLOCK, C.J. 1988. Fructan biosynthesis in excised leaves of Lolium temulentum L. II. Changes in fructosyltransferase activity following excision and application of inhibitors of gene expression. New Phytology 109:407-413.

CAIRNS, A.J., WINTERS, A. \& POLLOCK, C.J. 1989. Fructan biosynthesis in excised leaves of Lolium temulentum L. III. A comparison of the in vitro properties of fructosyl transferase activities with the characteristics on in vivo fructan accumulation. New Phytology 112:343-352.

CAIRNS, A.J., POLLOCK, C.J., GALlAGHER, J.A. \& HARRISON, J. 2000. Fructans: Synthesis and regulation. In Photosynthesis: physiology and metabolism (R.C. Leegood, T.D. Sharkey \& S. von Caemmerer, eds.). Kluwer, Netherlands, p.301-320.

DIXON, R.A., HOWLES, P.J., LAMB, C., KORTH, K, HE, X.-Z., SEWALT, V.J.H. \& RASMUSSEN, S. 1997. Plant secondary metabolism. Control points and prospects for genetic manipulation of phenylpropanoid biosynthesis. In Plant Cell and Tissue Culture for the Production of Food Ingredients (J. Fu, ed) Kluwer Academic/Plenum Publishing, New York, p.7-22.

DOUCE, R. \& NEUBURGER, M. 1989. The uniqueness of plant mitochondria. Annual Review Plant Physiology and Plant Molecular Biology 40:371-414. 
FARRAR, J.F., POLLOCK, C.J. \& GALLAGHER, J.A. 2000. Sucrose and the integration of metabolism in vascular plants. Plant Science 154:1-11.

FELL D. 1997. Understanding the control of metabolism. Portland Press, London.

FRICKE, W., LEIGH, R.A. \& TOMOS, A.D. 1994. Concentrations of inorganic and organic solutes in sap sampled from individual epidermal, mesophyll and bundle sheath cells of barley leaves. Planta 192:310-316.

GALlAGHER, J.A., KOROLEVA, O.A. TOMOS, A.D. FARRAR, J.F. \& POLLOCK, C.J. 2001. Single cell analysis technique for analysis of specific mRNA abundance in plant cells. Journal of Experimental Botany (in press).

GERHARDT, R. \& HELDT, H.W. 1984. Measurement of subcellular metabolite levels in leaves by fractionation of freeze-stopped material in non-aqueous media. Plant Physiology 75:542-547.

GRAHAM D. 1980. Effects of light on dark respiration. In The biochemistry of plants (D.D. Davies, ed.). Academic Press, New York, v.2, p.526-80.

HARRISON, J., GALLAGHER, J.A. \& POLLOCK, C.J. 1997. A simple and rapid method for the analysis of water-soluble carbohydrates from small segments of cereal leaf tissue. Journal of Plant Physiology 151:654-659.

HOUSLEY, T.L. \& POLLOCK, C.J. 1985. Photosynthesis and carbohydrate metabolism in detached leaves of Lolium temulentum L. New Phytology 99:499-505.

HUBER, S.C., BACHMANN, M., MCMICHAEL, R.W. \& HUBER, J.C. 1995. Regulation of sucrose phosphate synthase by reversible protein phosphorylation: Manipulation of activation and inactivation in vivo. In Sucrose metabolism, biochemistry, physiology and molecular biology (H. Pontis, G.L. Salerno \& E. Echeverria, eds.). American Society of Plant Physiologists, Rockville, p.6-13.

JELLINGS, A.J. \& LEECH, R.M. 1982. The importance of quantitative anatomy in the interpretation of whole leaf biochemistry in species of Triticum, Hordeum and Avena. New Phytology 92:39-48.

KAESER, W. 1983. Ultrastructure of storage cells in Jerusalem artichoke tubers (Helianthus tuberosus L.) Vesicle formation during inulin synthesis. Zeiscript Pflanzenphysiologie 111:253-260.

KAISER, G. \& HEBER, U. 1984. Sucrose transport into vacuoles isolated from barley mesophyll protoplasts. Planta 161:562-568.

KAISER, G., MARTINOIA, E. \& WIEMKEN, A. 1982. Rapid appearance of photosynthetic products in the vacuoles isolated from barley mesophyll protoplasts by a new fast method. Zeiscript Pflanzenphysiologie 107:103-113.

KINGSTON-SMITH, A.H. \& POLLOCK, C.J. 1996.

KOROLEVA, O.A., FARRAR, J.F., TOMOS, A.D. \& POLLOCK, C.J. 1997. Patterns of solute in individual mesophyll, bundle sheath and epidermal cells of barley leaves induced to accumulate carbohydrate. New Phytology 136:97-104
KOROLEVA, O.A., FARRAR, J.F., TOMOS, A.D. \& POLLOCK, C.J. 1998. Carbohydrates in individual cells of epidermis, mesophyll and bundle-sheath in barley leaves with changed export or photosynthetic rate. Plant Physiology 118:1525-32.

KOROLEVA, O.A., TOMOS, A.D., FARRAR, J.F., ROBERTS, P \& POLLOCK, C.J. 2000. Tissue distribution of primary metabolism between epidermal. Mesophyll and parenchymatous bundle sheath cells in barley leaves. Australian Journal of Plant Physiology 27:747-755.

KOROLEVA, O.A., TOMOS, A.D., FARRAR, J.F., GALLAGHER, J.A. \& POLLOCK, C.J. 2001. Expression of sucrose-fructan and fructosyl transferase gene in individual cells of barley leaves depends upon sugar status. Annals Applied Biology (in press).

KROMER, S. 1995. Respiration during photosynthesis. Annual Review Plant Physiology and Plant Molecular Biology 46:45-70.

LABHART, C., NOESBERGER, J. \& NELSON, C.J. 1983. Photosynthesis and degree of polymerisation of fructan during reproductive growth of meadow fescue at two temperatures and two photon flux densities. Journal of Experimental Botany 34:1037-46.

MATILE, P. 1987. The sap of plant cells. New Phytology 105:1-26.

POLLOCK, C.J. \& FARRAR, J.F. 1996. Source-sink relations: The role of sucrose. In Photosynthesis and the Environment (N.R. Baker, ed.). Netherlands, Kluwer, p.261-279.

POLLOCK, C.J. \& KINGSTON-SMITH, A.H. 1997. The vacuole and carbohydrate metabolism. In Advances in botanical research (R.A. Leigh \& D. Sanders, eds.). Academic Press, London, v.25, p.195-215.

POLLOCK, C.J., CAIRNS, A.J., GALLAGHER, J., MACHADO DE CARVALHO, M.A. \& KOCHHAR, A. 1999. The metabolism of sugars based upon sucrose. In Plant carbohydrate biochemistry (J.A. Bryant, M.M. Burrell, N.J. Kruger, eds.). BIOS Scientific Publishers, Oxford, p.47-60.

SIMPSON, R.J., WALKER, R.P. \& POLLOCK, C.J. 1991. Fructan exohydrolase in leaves of Lolium temulentum L. New Phytology 119:499-507.

SPRENGER, N., BORTLIK, K., BRANDT, A., BOLLER, T. \& WIEMKEN, A. 1995. Purification, cloning and functional expression of sucrose-fructan-6-transferase, a key enzyme of fructan synthesis in barley. Proceedings of Natural Academy of Science USA 92:11652-11656.

STITT, M. 1996. Metabolic regulation of photosynthesis In Photosynthesis and the environment (N.R. Baker, ed.). Kluwer, Netherlands, p.151-190.

TOMOS, A.D. \& LEIGH, R.A. 1999. The pressure probe: a versatile tool in plant cell physiology. Annual Review Plant Physiology and Plant Molecular Biology 50:447-472.

TOMOS, A.D., LEIGH, R.A., PALTA, J.A. \& WILLIAMS, J.H.H. 1992. Sucrose and cell water relations. In Carbon partitioning with and between organisms (C.J. Pollock, J.F. Farrar \& A.J. Gordon, eds.). Bios, Oxford, p.71-89.

WAGNER, W. \& WIEMKEN, A. 1986. Properties and subcellular localisation of fructan hydrolase in the leaves of barley (Hordeum vulgare L. cv.Gerbel). Journal of Plant Physiology 123:429-439. 
WAGNER, W., KELLER, F. \& WIEMKEN, A. 1983. Fructan metabolism in cereals: induction in leaves and compartmentation in protoplasts and vacuoles. Zeiscript Pflanzenphysiologie 112:359-372.

WILLIAMS, M.L., FARRAR, J.F. \& POLLOCK, C.J. 1989. Cell specialisation within the parenchymatous bundle sheath of barley. Plant Cell and Environment 12:909-918.

WINTER, H., LOHAUS G. \& HELDT, H.W. 1992. Phloem transport of aminoacids in relation to their cytosolic levels in barley leaves. Plant Physiology 99:996-1004.
WINTER, H., ROBINSON, D.G. \& HELDT, H.W. 1993. Subcellular volumes and metabolite concentrations in barley leaves. Planta 191:180-190.

WINTER, H., ROBINSON, D.G. \& HELDT, H.W. 1994. Subcellular volumes and metabolite concentrations in spinach leaves. Planta 193:530-535.

ZONDERVAN, A. \& SPARKS, R.J. 1997. Development plans for the AMS facility at the Institute of Geological and Nuclear Sciences, New Zealand. Nuclear Instruments \& Methods in Physics Research, Section B 123:79-83. 